\title{
PKM Kelompok Pendamping Diabetes Self Management Education (KP-DSME) Berbasis Keluarga di Kelurahan Penggaron Lor Kecamatan Genuk Kota Semarang
}

\author{
Dyah Wiji Puspita Sari, Rita Kartikasari, M. Abdurrouf \\ Universitas Islam Sultan Agung \\ daiyah_04@yahoo.com
}

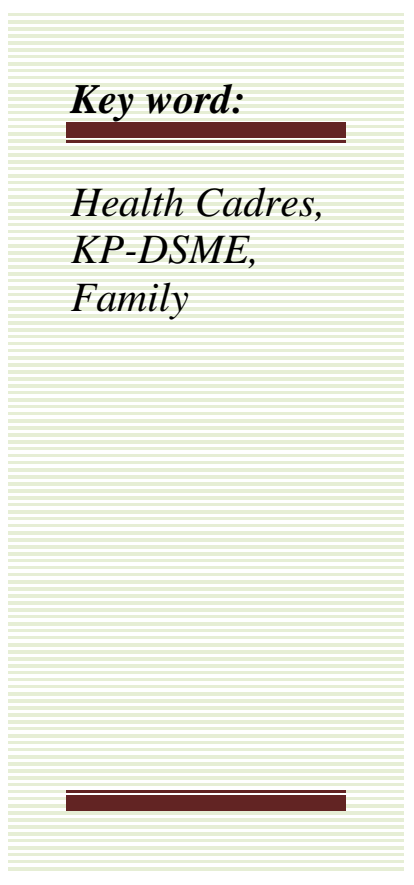

Kata Kunci

Kader

Kesehatan, $K P$ DSME,

Keluarga

\section{Abstract}

The service was done at Penggaron Lor Districk, especially in $R W$ $03 \&$ 04, there are many people with diabetes who lack the knowledge and skills in caring for family members suffering from Diabetes Mellitus at home. Community service activities in the form of Family-Based Self Management Education Support Group (KPDSME Keluarga) is one of the solutions to deal with this problem. The method used to carry out this Community service activities program are socialization, improvement of competence, implementation of activities, monitoring and evaluation. The resulting target and output is the implementation of science and technology on the self-care of diabetitian patients to health cadres in providing assistance to families who have diabetitian at home effectively based on recent literatures. The number of cadres involved in this PKM are 14 health cadres from PKK RW 3 and 4 $P K K$. The conclusion in this PKM activity is increasing the readiness of family members to perform self-care on family members who suffer from DM and increasing diabetee self care behavior.

\section{Abstrak}

Layanan ini dilakukan di RW 03 \& 04 Penggaron Lor, ada banyak penderita diabetes dan keluarganya tidak memiliki pengetahuan dan keterampilan dalam merawat Diabetes Mellitus di rumah. Kegiatan pelayanan masyarakat dalam bentuk Kelompok Pendamping Diabetes Self Management Education (KP-DSME) adalah salah satu solusi untuk mengatasi masalah ini. Metode yang digunakan untuk melaksanakan program kegiatan layanan masyarakat ini adalah sosialisasi, peningkatan kompetensi, pelaksanaan kegiatan, pemantauan dan evaluasi. Target dan luaran yang dihasilkan adalah implementasi sains dan teknologi pada perawatan diri pasien penderita diabetes untuk kader kesehatan dalam memberikan bantuan kepada keluarga yang memiliki diabetisi di rumah secara efektif berdasarkan literatur terbaru. Jumlah kader yang terlibat dalam PKM ini adalah 14 kader kesehatan. Kesimpulan dalam kegiatan PKM ini adalah mengingkatnya kesiapan anggota keluarga untuk melakukan perawatan diri pada anggota keluarga yang menderita DM dan meningkatkan perilaku perawatan diri diabetesi. 


\section{PENDAHULUAN}

Diabetes Melitus (DM) adalah penyakit metabolik kronis yang disebabkan oleh ketidakmampuan tubuh untuk memproduksi hormon insulin sesuai kebutuhan atau karena penggunaan yang tidak efektif dari insulin atau keduanya. Gangguan tersebut dapat disebabkan oleh sekresi hormon insulin tidak adekuat atau fungsi insulin terganggu (Resistensi insulin). Secara garis besar DM dikelompokkan menjadi 2 tipe, yaitu: DM tergantung pada insulin (DM tipe-1) dan DM tidak tergantung pada insulin (DM tipe-2) (Stevens, 2002).

Di dunia pada tahun 2010 diperkirakan ada sekitar 59 juta orang yang menderita DM dan pada tahun 2030 diperkirakan akan meningkat 2,5 kali lipat sehingga mencapai 145 juta penderita. Di Indonesia sendiri, World Health Organization (WHO) memperkirakan jumlah penderita diabetes mellitus di Indonesia meningkat tiga kali lipat dari data tahun 2000 dimana jumlah penderita mencapai 8,4 juta , maka dalam 10 tahun tepatnya tahun 2010 mencapai 21,3 juta orang (PERKENI, 2006). Upaya untuk mengurangi resiko tersebut, maka diperlukan suatu program penatalaksanaan diabetes secara mandiri bagi para diabetisi ini (Sutandi, 2012).

Pengendalian DM akan lebih efektif bila diprioritaskan pada pencegahan dini melalui upaya perawatan mandiri pasien di keluarga. Program Self-management dapat mendorong pasien menggunakan sumber daya yang ada untuk mengelola gejala yang dialaminya terutama pada pasien dengan penyakit kronis (Warsi et al, 2004). Diabetes Self-Management Education (DSME) merupakan proses pendidikan kesehatan bagi individu atau keluarga dalam mengelola penyakit diabetes. DSME menggunakan metode pedoman, konseling, dan intervensi perilaku untuk meningkatkan pengetahuan mengenai diabetes dan meningkatkan ketrampilan individu dan keluarga dalam mengelola penyakit DM (Jack et al., 2004).

Tujuan dari kegiatan Kelompok Pendamping Diabetes Self Management Education (KP-DSME Keluarga) adalah meningkatkan pengetahuan, keterampilan, dan kemampuan keluarga dalam melaksanakan perawatan mandiri pada anggota keluarga yang menderita DM, meningkatkan self care behavior pada pasien DM sehingga status kesehatan dan kualitas hidup masyarakat khususnya pada penderita DM meningkat.

Kelurahan Penggaron Lor merupakan salah satu kelurahan di Kecamatan Genuk Semarang. Jumlah penduduk Kelurahan Penggaron Lor adalah 4.097 orang, dengan proporsi laki-laki dan wanita hampir sama dan jumlah anak kurang lebih 2 setiap keluarganya (Data Monografi Kelurahan Penggaron Lor, 2010). Di kelurahan ini terdapat banyak diabetisi yang melakukan perawatan mandiri di rumah secara bertahun-tahun. Banyak diantara keluarga dan penderita diabetisi yang mengeluhkan stres melakukan perawatan pada anggota keluarganya yang sakit DM, serta beberapa yang lain mengeluhkan kurangnya pengetahuan dan ketrampilan yang memadai 
untuk melakukan perawatan mandiri di rumah secara optimal.

Tim penggerak PKK kelurahan Penggaron Lor terdiri dari 10 Kelompok Kerja (Pokja). Salah satu Pokja yaitu Pokja 4 khusus mengelola Program Kesehatan, Kelestarian Lingkungan Hidup, dan Perencanaan Sehat. Pada pengelolaan program kesehatan dan perencanaan sehat masyarakat belum terdapat program kelompok pendampingan pada keluarga dengan anggota keluarga yang menderita penyakit DM. Program ini dibutuhkan untuk mempersiapkan keluarga dalam merawat anggota keluarga yang menderita DM.

\section{METODE PELAKSANAAN}

Metode dalam pelaksanaan PKM ini dilakukan dalam 4 ( empat ) tahapan, yaitu (1) Sosialisasi, (2) Peningkatan kompetensi, (3) Pelaksanaan kegiatan, serta (4) Monitoring dan Evaluasi. Penggunaan 4 metode ini efektif digunakan untuk memberikan peningkatan pengetahuan dan ketrampilan kader kesehatan dalam kesiapannya melakukan pendampingan kepada keluarga pasien DM. Kegiatan pendampingan yang dilakukan oleh TIM pengabdian ini menjadi cara yang digunakan untuk memberdayakan kader kesehatan sehingga tujuan dari pengabdian masyarakat tercapai.

Metode sosialisasi dilaksanakan untuk memberikan pemahaman mengenai program PKM dan alur serta tahapan program PKM. Sedangkan metode peningkatan kompetensi kader kesehatan dilakukan melalui curah pendapat mengenai cara perawatan mandiri pasien DM kepada pasien dan keluarga dan pemahaman pada Mitra tentang cara perawatan mandiri pasien DM di rumah.

Metode pelaksanaan kegiatan ini dilakukan dengan menjalin kerjasama dengan pusat pelayanan kesehatan terdekat dengan masyarakat (Puskesmas) dan melakukan pendampingan pada kader dalam melakukan perawatan mandiri pasien DM di rumah. Kerjasama dengan Puskesmas dilaksanakan dalam rangka melaksanakan tanggungjawab bersama untuk menyelenggarakan pembangunan kesehatan dan membina peran serta masyarakat untuk meningkatkan kualitas hidup masyarakat.

Pada pelaksanaan kegiatan tahap pendampingan kader kesehatan, kader yang ditunjuk adalah Tim penggerak PKK Kelurahan Penggaron Lor yaitu Pokja 4 yang khusus mengelola Program Kesehatan, Kelestarian Lingkungan Hidup, dan Perencanaan Sehat. Jumlah kader yang terlibat sebanyak 14 orang. Mereka menjadi kader kesehatan untuk kegiatan PKM KP-DSME berbasis keluarga ini. Tim pengabdian melakukan pendampingan kepada kader kesehatan dengan tindak 
lanjut kader kesehatan mendampingi keluarga yang memiliki anggota keluarga dengan penyakit Diabetes mellitus. Harapannya anggota yang mendapatkan pendampingan dari kader kesehatan ini akan mencapai kemandirian dalam melakukan perawatan pasien DM secara mandiri.

Proses pendampingan yang dilakukan oleh kader kesehatan ke anggota keluarga dilaksanakan melalui kunjungan rumah tiap bulan sekali untuk mengajarkan perawatan mandiri pasien DM serta melakukan kontrol secara langsung terhadap kesehatan pasien DM. Hasil proses kontrol tersebut diantaranya adalah terkontrolnya kadar gula darah, kolesterol, tekanan darah, index massa tubuh, ketaatan minum obat, serta kemampuan manajemen stres pasien. Setiap satu orang kader kesehatan akan mengelola 1-3 anggota keluarga diabetisi.

Pada tahap monitoring dan evaluasi dilaksanakan setiap bulan sekali. Pelaksanaan monev dilaksanakan dengan cara seluruh kader kesehatan dan pembina wilayah puskesmas dikumpulkan untuk dilakukan monev terhadap pelaksanaan kegiatan selama KP-DSME berlangsung. Apabila dalam proses pelaksanaan kegiatan ditemukan kendala oleh para kader, tim pengabdian memberikan pembinaan dan penguatan terhadap masalah yang ditemukan. Proses seluruh pelaksanaan kegiatan pengabdian ini dilaksanakan dengan menggunakan alur sebagai berikut: Sosialisasi, (2) Peningkatan kompetensi, (3) Pelaksanaan kegiatan, serta (4) Monitoring dan Evaluasi Pelaksanaan kegiatan ini dilaksanakan di Kelurahan Penggaron Lor Kecamatan Genuk Kota Semarang dari bulan Februari hingga Agustus 2018. Teknik pengumpulan data dilakukan dengan menggunakan kuesioner.

\section{HASIL PEMBAHASAN}

Pelaksanaan kegiatan PKM Kelompok Pendamping Diabetes Self Management Education Berbasis Keluarga (KP-DSME KELUARGA) telah dilaksanakan melalui tahapan sosialisasi, peningkatan kompetensi, pelaksanaan kegiatan, serta monitoring dan evaluasi. Melalui metode sosialisasi memberikan hasil bahwa kader kesehatan memahami, mempunyai pola fikir dan mempunyai komitmen dalam meningkatkan derajat kesehatan khususnya keluarga diabetisi. Salah satu langkah untuk mencapai suatu kesuksesan sebuah program ialah melalui sosialisasi. 


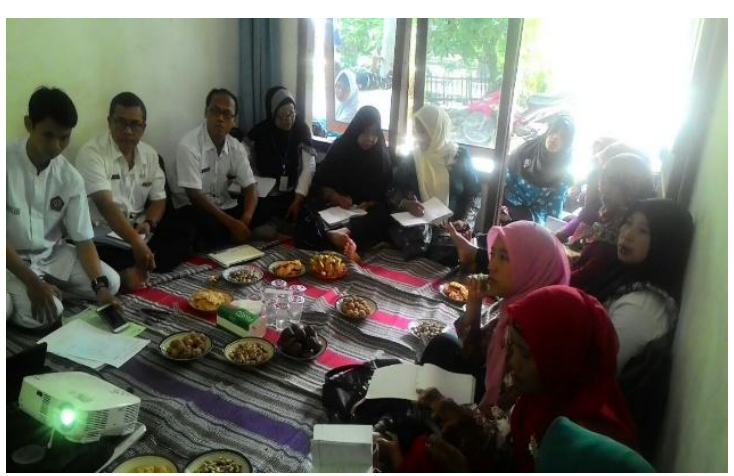

Gambar 1. Pelaksanaan Sosialisasi kepada: (a) Petugas puskesmas (sisi kiri), (b) Mitra (sisi kanan)

Pada metode peningkatan kompetensi, sebelumnya dilakukan pengumpulan informasi kepada kader kesehatan dengan menggunakan kuesioner tentang segala hal yang berkaitan dengan perawatan mandiri pasien DM di rumah seperti bagaimana perencanaan pola makan dan diet yang tepat, cara memonitoring kadar gula darah secara berkala, cara olahraga dan latihan yang tepat pada penderita DM, dll dilanjutkan dengan pemberian materi dan diakhiri dengan evaluasi tentang pengetahuan dan ketrampilan kader setelah pemberian materi. Hasil pengumpulan informasi awal tentang pengetahuan dan kemampuan kader berkaitan dengan perawatan mandiri pasien DM di rumah menunjukkan hampir seluruh kader kesehatan belum memahami tentang perawatan mandiri pasien DM di rumah. Setelah dilaksanakan proses pendampingan oleh TIM PKM maka kemampuan kader kesehatan tentang perawatan mandiri pasien DM di rumah mengalami peningkatan yang signifikan.

Pada pelaksanaan kegiatan PKM ini dilaksanakan dengan bekerjasama melibatkan pusat pelayanan kesehatan terdekat dengan masyarakat yaitu Puskesmas Bangetayu. Terdapat dua orang dari puskesmas yang bertugas sebagai Pembina wilayah pada kegiatan PKM ini. Pembina wilayah ini dibagi menjadi Pembina wilayah RW 3 dan RW 4 yang bertugas untuk mendampingi kader kesehatan dalam pelaksanaan pendampingan ke keluarga pasien DM. Peran dari puskesmas sangat mendukung keberhasilan kegiatan PKM ini.

DepKes RI (2004), Puskesmas adalah unit pelaksana teknis Dinas Kesehatan Kabupaten atau Kota yang bertanggung jawab menyelenggarakan pembangunan kesehatan di suatu wilayah kesehatan. Puskesmas merupakan pusat pengembangan kesehatan masyarakat dalam membina peran serta masyarakat juga memberikan pelayanan secara menyeluruh dan terpadu kepada masyarakat. Puskesmas mempunyai wewenang dan tanggung awab atas pemeliharaan kesehatan masyarakat dalam wilayah kerjanya. Pelayanan kesehatan yang diberikan puskesmas adalah pelayanan kesehatan menyeluruh yang meliputi pelayanan: kuratif (pengobatan), 
preventif (upaya pencegahan), promotif (peningkatan kesehatan), dan rehabilitatif (pemulihan kesehatan).

Selain itu, dalam pelaksanaan kegiatan ini juga dilakukan pendampingan pada kader kesehatan dalam melakukan perawatan mandiri pasien DM di rumah. Pendampingan ini terdiri dari kegiatan perencanaan pola makan dan diet yang tepat, cara memonitoring kadar gula darah secara berkala, cara olahraga dan latihan yang tepat pada penderita DM, cara mengurangi resiko seperti luka DM yang sukar sembuh, managemen stress, dan pengobatan yang teratur, penyampaian materi pelatihan tentang masalah pasien dengan DM, mendemonstrasikan cara perencanaan pola makan dan diet yang tepat, cara memonitoring kadar gula darah secara berkala, cara olahraga dan latihan yang tepat pada penderita DM atau senam DM, cara mengurangi resiko seperti luka DM yang sukar sembuh, serta cara managemen stress. Seluruh kegiatan ini dilakukan dengan metode pelatihan, role play, pemberian pendidikan kesehatan, dan penyuluhan.

Cushway (2001) menyebutkan bahwa pelatihan bertujuan untuk mengembangkan keahlian dan dan kemampuan individu untuk memperbaiki kinerja, membiasakan pegawai dengan sistim, prosedur dan metode kerja yang baru, serta membantu pegawai dan pendatang baru menjadi terbiasa dengan persyaratan pekerjaan tertentu dan persyaratan organisasi.

Pemberian pendidikan kesehatan dan penyuluhan pada hakikatnya merupakan suatu kegiatan untuk menyampaikan pesan kepada masyarakat, kelompok, atau individu dengan harapan kelompok tersebut mendapatkan pengetahuan tentang kesehatn yang lebih baik. Hal ini seirama dengan pendapat Notoadmodjo (2005) yang menyatakan bahwa informasi akan berpengaruh terhadap pengetahuan seseorang. Pada kegiatan pendidikan kesehatan dan penyuluhan ini TIM PKM menggunakan berbagai media diantaranya power point, leaflet, dan lembar balik.

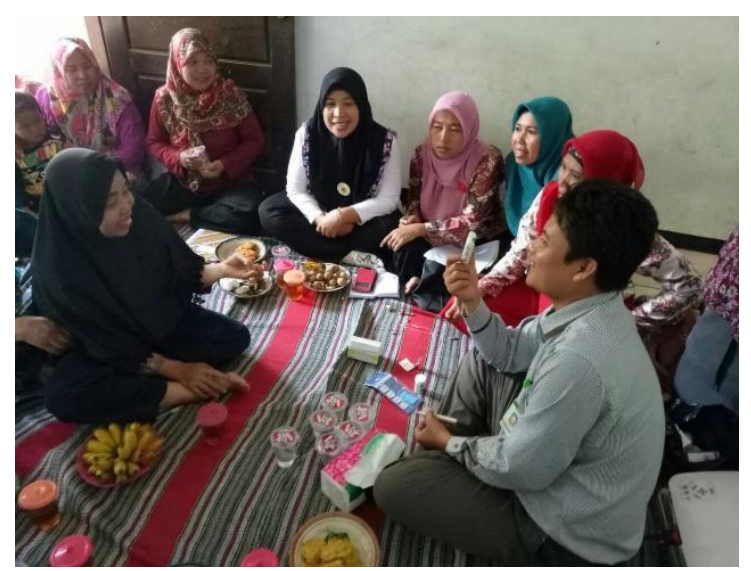

Gambar 2. Pendampingan Pada Kader Kesehatan

Pada metode monitoring dan evaluasi dilaksanakan setiap bulan sekali dengan cara seluruh kader kesehatan dan 
pembina wilayah puskesmas dikumpulkan untuk dilakukan monev terhadap pelaksanaan kegiatan selama KP-DSME berlangsung. Monitoring dan evaluasi merupakan sebuah proses yang berkesinambungan meliputi pengumpulan data, proses dan pemilihan informasi mengenai implementasi proyek, progress yang dicapai pada proyek tersebut sampai kepada dampak dan efek dari adanya proyek tersebut (Ojha, 1998). Hasil riset yang dilakukan oleh Muktiali (2009) menunjukkan bahwa kegiatan monitoring dan evaluasi diperlukan untuk melihat tingkat keberhasilan dan ketercapaian tujuan dan manfaat program-program pembangunan Kota Semarang.

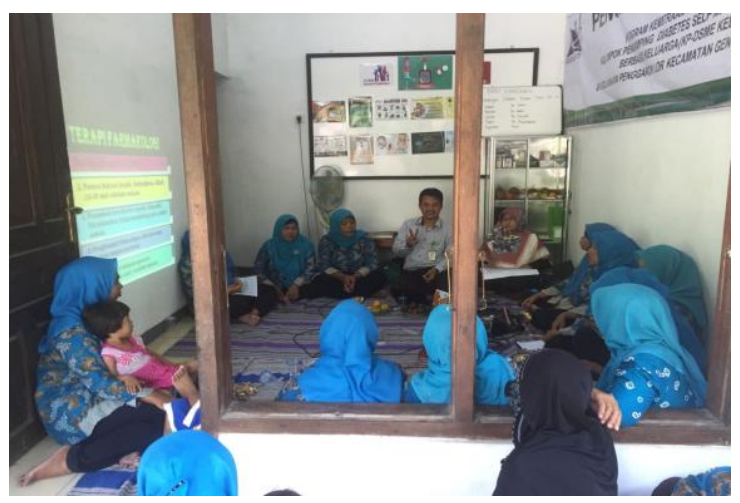

Gambar 3. Kegiatan Monev

Berdasarkan hasil monitoring evaluasi juga didapatkan peningkatan yang signifikan pada kualitas hidup diabetisi. Hasil pengontrolan kadar gula darah didapatkan data bahwa sebagian besar kadar gula darah diabetisi terkontrol dengan baik. Hal ini menunjukkan bahwa PKM KP-DSME memiliki peran yang cukup signifikan dalam meningkatkan kualitas hidup diabetisi.

Keunggulan Program Pengabdian Masyarakat Kelompok Pendamping Diabetes Self Management Education Berbasis Keluarga (KP-DSME Keluarga) yaitu menjadi strategi yang efektif dan terintegrasi, berbasis masyarakat melalui kerjasama lintas program dan lintas sektor untuk meningkatkan kualitas hidup masyarakat yang menderita Diabetes Mellitus. Pada Pelaksanaan kegiatan pengabdian ini tidak dialami kesulitan yang signifikan karena kader kesehatan dan Puskesmas mampu bekerjasama dengan sangat baik.

\section{SIMPULAN}

Pengabdian masyarakat Kelompok Pendamping Diabetes Self Management Education Berbasis Keluarga (KP-DSME Keluarga) dapat disimpulkan bahwa terbentuknya forum diskusi kader kesehatan yang berfokus pada DM dibawah binaan Puskesmas Bangetayu, meningkatnya kemampuan dan ketrampilan kader kesehatan terkait perawatan mandiri pasien DM dari $20 \%$ menjadi $85 \%$, meningkatnya kesiapan anggota keluarga untuk melakukan perawatan mandiri pada anggota keluarga 
yang menderita DM dan self care behavior pada pasien DM dari $30 \%$ menjadi $80 \%$. KP-DSME berbasis Keluarga menjadi strategi yang tepat untuk memberdayakan masyarakat dalam rangka meningkatkan kesiapan anggota keluarga untuk melakukan perawatan mandiri pada anggota keluarga yang menderita DM dan self care behavior pada pasien DM. Rekomendasi untuk kegiatan PKM selanjutnya adalah mengembangakan KPDSME berbasis Keluarga di seluruh RW Kelurahan Penggaron Lor dan tidak hanya berfokus pada DM tetapi juga pada penyakit kronis tidak menular lainnya.

\section{SARAN}

Program kegiatan KP-DSME Berbasis keluarga ini masih berada dalam lingkup yang kecil tetapi telah memberikan dampak yang cukup baik dalam perawatan mandiri diabetisi di rumah, sehingga diharapkan menjadi inisiasi awal bagi puskesmas atau dinas kesehatan terkait untuk menjadikan KP-DSME Berbasis Keluarga ini sebagai program kesehatan unggulan penanganan penyakit tidak menular khususnya penyakit diabetes melllitus di Kelurahan Penggaron Lor Kota Semarang.

\section{UCAPAN TERIMAKASIH}

Ucapan rasa terima kasih yang sebesarbesarnya penulis ucapkan kepada Kementrian Riset Teknologi dan Pendidikan Tinggi yang telah memberikan Biaya Pengabdian Masyarakat tahun penerimaan 2017, serta terimakasih kepada Lembaga Penelitian dan Pengabdian Masyarakat Unissula yang telah memfasilitasi dan mendorong penulis dalam melaksanankan pengabdian masyarakat ini hingga selesai dengan baik.

\section{DAFTAR PUSTAKA}

American Diabetes Association. 2011. Diabetes Statistics: 2011 National diabetes fact sheet. http://www.diabetes.org/diabetesbasics/diabetes-statistics/. November 10th, 2011.

Stevens J, Ahn K, Juhaeri, Houston D, Steffan L, Couper D. 2002. Dietary Fiber Intake and Glycemic Index and Incidence of Diabetes in AfricanAmerican and White Adults: the ARIC Study.Diabetes Care $25: 1715-21$

Cushway B. 2001. Manejemen Sumber Daya Manusia. Jakarta: Gunung Agung.

Dahmiri, Sakta. 2014. Pengaruh Pelatihan terhadap Kinerja Pegawai Dinas Pendidikan Kabupaten Sarolangun. Mankeu, Vol. No. 3 No.1 2014:374463.

Departemen Kesehatan RI. 2004. Pedoman Penyelenggaraan Puskesmas di Era Desentralisasi. Jakarta: Balai Pustaka 
Muktiali M. 2009. Penyusunan Instrumen Monitoring Dan Evaluasi Manfaat Program Pembangunan Di Kota Semarang. Riptek, Vol.3, No.2, Tahun 2009, Hal.: 11 - 20

Nainggolan N. 2013. Dampak Sosialisasi Program Keluarga Berencana Dalam Pengambilan Keputusan Keluarga Untuk Menggunakan Kontrasepsi Di Kecamatan Samarinda Ulu Kota Samarinda. eJournal llmu Komunikasi，2013， 1 (2): 389-399 ISSN 0000-0000, ejournal.ilkom.fisip-unmul.ac.id

Notoadmodjo. 2005. Metodologi Penelitian Kesehatan Edisi Revisi. Jakarta: PT Rineka Cipta

Ojha D. 1998. Impact Monitoring Approaches and Indicators. GTZ: Escborn

PERKENI. 2006. Konsensus pengelolaan DM tipe 2 di Indonesia. Jakarta: PB PERKENI

Rahayu E, Kamaluddin R, Sumarwati M. 2014. Pengaruh Program Diabetes Self Management Education Berbasis Keluarga Terhadap Kualitas Hidup Penderita Diabetes Melitus Tipe II Di Wilayah Puskesmas II Baturraden. Jurnal Keperawatan Soedirman (The Soedirman Journal of Nursing), Volume 9, No.3, Juli 2014

Sutandi, A. 2012. Diabetes Self Management Education (DSME) sebagai metode alternative dalam perawatan mandiri pasien diabetes mellitus di dalam keluarga. $E$ Journal Widya, vol 29, no 321

Warsi, et al. 2004. A systemic review and methodological critique of the literature: original invertigation self management education programs in chroni deseases. Intern med, vol 164, Aug 9/23

Yuanita, Wantiyah, Susanto. 2014. Pengaruh diabetes self management education terhadap resiko terjadinya ulkus diabetik pada pasien rawat jalan dengan DM type II di RSD Jember E-journal Kesehatan, Vol 2, No 1, Januari, 2014 